\title{
ORGANIC MULCHES AFFECT SOIL AND LEAF NUTRIENT LEVELS OF YOUNG PECAN TREES
}

\author{
by Wheeler G. Foshee, III, ${ }^{1}$ William D. Goff, ${ }^{2}$ Michael G. Patterson, ${ }^{3}$ Kenneth M. Tilt, ${ }^{2}$ \\ W. Alfred Dozier, Jr., ${ }^{2}$ Laura S. Tucker, ${ }^{4}$ and James S. Bannon ${ }^{5}$
}

\begin{abstract}
Soil and leaf nutrient levels were compared from young pecan (Carya illinoensis [Wangenh.] K. Koch) trees mulched with leaves, pine bark nuggets, pine straw, grass clippings, or chipped limbs; and from unmulched trees with bermudagrass sod. Soil beneath grass-clipping mulch showed an increase in soil potassium (K) levels as compared to all other treatments except chipped limbs. Foliar iron (Fe) for the pine bark nuggets and leaf treatments were higher than for the pine-straw and chippedlimb treatments. Leaf manganese $(\mathrm{Mn})$ levels for the grass-clipping treatment were higher than those for sod, pine straw, chipped limbs, or leaf treatments. Overall, the nutritional differences among mulch treatments were small, suggesting that growth differences were attributed to other factors.
\end{abstract}

Key Words. Mulches; soil nutrients; leaf nutrients.

Mulches increase soil organic matter and provide a plant nutrient source (Ashworth and Harrison 1983). Jacks et al. (1955) cited that mulching increased soil nutrient concentrations in apple and peach orchards and in forests. In an experiment with tomatoes, Holmes et al. (1948) reported that straw mulch markedly increased soil potassium (K) concentrations. According to Harris (1983), increased nutrient concentrations in soils with organic mulches occur through direct leaching or decomposition. Merwin et al. (1995) reported that hay mulch increased topsoil nitrate $\left(\mathrm{NO}_{3}\right), \mathrm{K}$, and magnesium $(\mathrm{Mg})$ concentrations in apple leaves when compared to herbicide or synthetic mulch-treated soils. Foliar $K$ concentrations in apples were also greater when hay or wood chips were used as a mulch compared to synthetic mulches, but long-term benefits of mulching on fertility were inconsistent. Fraedrich and Ham (1982) reported that wood-chip mulching increased soil $\mathrm{K}$ concentrations around maple trees. Gartner (1978) found an increase in soil calcium (Ca), $\mathrm{Mg}$, and $\mathrm{K}$ concentrations when hardwood bark was used as a mulch for shrubs. DeFrank and Foss (1989) found that macadamia trees mulched with macadamia husks increased foliar $\mathrm{K}$ concentra- tions as mulch depth increased. Gupta (1991) reported that various tree species had increased foliar $\mathrm{K}$ concentrations when grown with a surface mulch of coirpith, a coconut byproduct.

Growth of young pecan trees is substantially enhanced by mulching (Foshee et al. 1996). 'Desirable' pecan trees are sensitive to nutrient imbalances (Sparks 1997), especially to nitrogen-potassium imbalance. The purpose of this study was to examine the nutrient status of young, mulched pecan trees.

\section{MATERIALS AND METHODS}

Container-grown pecan trees (Carya illinoensis 'Desirable') were planted in October 1991 on a $100 \times$ $115 \mathrm{~m}(30 \times 35 \mathrm{ft})$ spacing at the E.V. Smith Research Center in central Alabama on a Cahaba fine sandy loam (fine, loamy, siliceous, thermic, Typic Hapludults) soil. The trees were sized (circumference), ranked, and planted in a randomized complete block design with 4 single-tree replications. Trees of similar size were planted within blocks. Each block contained 5 mulch types (hardwood leaves, pine bark nuggets, pine straw, grass clippings, and chipped limbs) each at 3 depths-15, 30, and $45 \mathrm{~cm}(6,12$, and $18 \mathrm{in}$.); and a plot of common bermudagrass sod was laid around trees at time of initial mulch application. All 16 treatments were maintained in a $3 \times 3 \mathrm{~m}(10 \times 10 \mathrm{ft})$ area centered on the trees.

Mulches were applied initially in February 1992 and replenished annually in 1993 and 1994 during the dormant season to maintain specific depths. Trees were fertilized uniformly with commercialgrade fertilizer based on leaf and soil analyses (O'Barr et al. 1989) taken from all treatments and averaged. Nitrogen $(N)$ was applied underneath each tree at a rate $0.3,0.6$, and $1.3 \mathrm{~kg}(0.7,1.4$, and $2.9 \mathrm{lb})$ actual $\mathrm{N}$ per $90 \mathrm{~m}^{2} /$ year $\left(1,000 \mathrm{ft}^{2} /\right.$ year $)$ from ammonium nitrate in 1993, 1994, and 1995-1996, respectively. This $N$ application was split into 3 ap- 
plications approximately 30 days between each application, with the first application applied in late February. During this period, no additional phosphorous $(\mathrm{P}), \mathrm{K}$, or zinc $(\mathrm{Zn})$ was required based on the averages of soil and foliar analyses and none was applied. Trees received no supplemental irrigation but were otherwise maintained according to standard recommendations for pecans (Worley 1989).

Foliage samples were taken in July 1994 by collecting 50 leaflets from the middle of compound leaves at the midpoint of the current season's shoots of each tree. Leaflets were rinsed briefly in tap water containing $2 \%(\mathrm{v} / \mathrm{v})$ detergent to remove surface contaminants, then rinsed again in water and allowed to dry before analysis as described by O'Barr et al. (1989). Samples were analyzed for boron (B), $\mathrm{Ca}$, copper (Cu), Fe, K, Mg, Mn, N, P, and Zn using a dry ash technique (Hue and Evans 1986). Soil samples were collected in July 1994 within the $3 \times$ $3 \mathrm{~m}(10 \times 10 \mathrm{ft})$ treated area surrounding each tree to a depth of $20 \mathrm{~cm}$ (8 in.). These samples were analyzed for the same nutrients and for soil pH using established procedures (Mehlich 1953; Hue and Evans 1986). Data were analyzed with the SAS GLM procedure (SAS Institute 1991).

\section{RESULTS AND DISCUSSION}

Among the organic mulches, neither mulch type nor depth affected soil or foliar nutrient concentrations, with the exception of soil $\mathrm{K}(P=0.0269)$ and foliar $\mathrm{Fe}(P=0.0104)$. The plots mulched with grass clippings had higher soil $\mathrm{K}$ concentrations (126 ppm) than did plots mulched with hardwood leaves (53 ppm), pine straw (53 ppm), or pine bark nuggets $(43 \mathrm{ppm})$. The chipped-limb mulch treatment had lower foliar Fe levels (78 ppm) than did plots mulched with leaves (125 ppm), pine bark nuggets (125 ppm), or grass clippings (112 ppm).

When the organic mulches were compared to all treatments, including the bermudagrass sod, similar trends were observed. Plots mulched with grass clippings had higher soil $\mathrm{K}$ concentrations than any other treatment (Table 1). Foliar Fe for the pinebark-nugget and hardwood-leaf treatments were higher than for the pine-straw and chipped-limb treatments (Table 1). All treatments were within Fe sufficiency ranges for pecan growth $(0.75 \%$ to $0.95 \%$ ) (O'Barr et al. 1989). Leaf $M$ for the grass- clipping treatment were higher than those for bermudagrass sod, pine straw, chipped limb, or leaf treatments (Table 1). Again, all treatments were within $\mathrm{Mn}$ sufficiency ranges (100 to $800 \mathrm{ppm}$ ) (O'Barr et al. 1989).

Foliar $\mathrm{K}$ levels were not affected by any of the treatments $(P=0.2697)$. All treatments were within the $\mathrm{K}$ sufficiency ranges for optimal pecan growth (0.75\% to $0.95 \%$ ) suggested by O'Barr et al. (1989). Foliar $\mathrm{N}$ concentrations were not affected by any treatment $(P=0.5674)$. However, it is noteworthy that trees in all treatments were below the minimum recommended $\mathrm{N}$ concentrations for pecan trees (range $2.70 \%$ to $2.90 \%$ ) (O'Barr et al. 1989). The nitrogen level for the mulched group was $2.20 \%$ and for the sod plots, $2.17 \%$. Soil pH levels were unaffected by the treatments $(P=0.0594)$.

Increased growth, as measured by trunk crosssectional area (TCSA), for mulched trees observed in this study were reported previously (Foshee et al. 1996). Mulched trees grew approximately $60 \%$ more in TCSA than with bermudagrass sod treatments. This study demonstrated that trees mulched with grass-clipping mulch had higher soil $\mathrm{K}$ concentrations than all other treatments. In addition, some mulch treatments showed increased foliar Fe and Mn levels. Overall, no other significant nutritional differences or trends were found. It is likely that other effects attributed to mulching-such as moisture conservation, evaporation reduction (Russel 1939),

Table 1. Effect of mulch treatments on concentration of soil K, and concentration of foliar Fe and $\mathrm{Mn}^{\mathrm{z}}$

\begin{tabular}{|c|c|c|c|}
\hline \multirow[b]{2}{*}{ Treatment } & \multicolumn{3}{|c|}{ Nutrient concentration } \\
\hline & $\begin{array}{l}\text { Soil K } \\
\text { (ppm) }\end{array}$ & $\begin{array}{l}\text { Foliar Fe } \\
(\mathrm{ppm})\end{array}$ & $\begin{array}{l}\text { Foliar Mn } \\
\text { (ppm) }\end{array}$ \\
\hline Grass clippings & $126 a^{y}$ & $112 a b$ & $1,453 \mathrm{a}$ \\
\hline Chipped limbs & $75 \mathrm{~b}$ & $78 \mathrm{c}$ & $764 c$ \\
\hline Hardwood leaves & $53 \mathrm{~b}$ & $125 \mathrm{a}$ & $622 \mathrm{c}$ \\
\hline Pine straw & $53 \mathrm{~b}$ & $86 b c$ & $816 \mathrm{bc}$ \\
\hline Pine bark nuggets & $43 \mathrm{~b}$ & $125 \mathrm{a}$ & $1,265 \mathrm{ab}$ \\
\hline Bermudagrass sod & $54 b$ & $108 \mathrm{abc}$ & $987 \mathrm{bc}$ \\
\hline \multicolumn{4}{|l|}{ Significance } \\
\hline Treatment & .0091 & .0284 & .0111 \\
\hline
\end{tabular}


and increased soil organic matter (Ashworth and Harrison 1983)—contributed substantially to observed growth differences.

Information from this study is applicable to establishment of young trees in the urban forest and orchards. Pecans are a particularly suitable tree for evaluating nutritional effects of mulches, due to extensive literature available on foliar nutrient sufficiency ranges.

\section{LITERATURE CITED}

Ashworth, S., and H. Harrison. 1983. Evaluation of mulches for use in the home garden. HortScience 18:180-182.

DeFrank, J., and S.L. Foss. 1989. Yield and growth of macadamia trees in response to mulching with macadamia husks. HortScience 24:392.

Foshee, W.G., W.D. Goff, K.M. Tilt, J.D. Williams, J.S. Bannon, and J.B. Witt. 1996. Organic mulches increase growth of young pecan trees. HortScience 31:811-812.

Fraedrich, S.W, and D.L. Ham. 1982. Wood chip mulching around maples: Effect on tree growth and soil characteristics. J. Arboric. 8:85-89.

Gartner, J.B. 1978. Using bark and wood chips as a mulch for shrubs and evergreens. Am. Nurseryman 147:9-10, $53-55$.

Gupta, G.N. 1991. Effects of mulching and fertilizer application on initial development of some tree species. For. Ecol. Manage. 44:211-221.

Harris, R.W. 1983. Arboriculture: Care of Trees, Shrubs, and Vines in the Landscape. Prentice Hall, Englewood Cliffs, NJ.

Holmes, A.D., C. Tyson-Smith, C. Rodgers, and W.H. Lockman. 1948. Effect of different mulches upon the nutritive value of tomatoes. Soil Sci. 65:471-475.

Hue, N.V., and C.E. Evans. 1986. Procedures used for soil and plant analysis by the Auburn University soil testing laboratory. Dept. of Agron. \& Soils, Auburn Univ. Dept. Series 106.

Jacks, G.V., W.D. Brind, and R. Smith. 1955. Mulching. Tech. Comm. No. 49. Cmwlth. Bur. of Soil Sci.

Mehlich, A. 1953. Determinations of $\mathrm{P}, \mathrm{Ca}, \mathrm{Mg}, \mathrm{K}, \mathrm{Na}$, and $\mathrm{NH}_{4}$ by North Carolina soil testing laboratories. NC Dept. of Agric., Raleigh, NC.

Merwin, I.A., D.A. Rosenberger, C.A. Engle, D.L. Rist, and M. Fargione. 1995. Comparing mulches, herbicides, and cultivation as orchard groundcover management systems. Hort Technology 5:151-158.

O'Barr, R.D., M. Smith, G. Taylor, and W.D. Goff. 1989. Pecan nutrition, p 6172. In Goff, W.D., J.R. McVay, and W.S. Gazaway (Eds.). Pecan Production in the
Southeast: A Guide for Growers. Ala. Coop. Ext. Serv., Auburn Univ.

Russel, J.C. 1939. The effects of surface cover on soil moisture losses by evaporation. Proc. Soil Sci. Soc. Am. 4:65-70.

SAS Institute. 1991. SAS User's Guide: Statistics. Version 6. SAS Institute Inc., Cary, NC.

Sparks, Darrell. 1997. 'Desirable' pecan. Fruit Var. J. $51(1): 2-7$

Worley, R. 1989. Establishing an orchard, pp 52-58. In W.D. Goff, J.R. McVay, and W.S. Gazaway (Eds.). Pecan Production in the Southeast: A Guide for Growers. Ala. Coop. Ext. Serv., Auburn Univ.

Acknowledgements. Alabama Agricultural Experiment Station Journal Series No. 11-975840.

${ }^{1 *}$ Former graduate research assistant, Department of Horticulture

${ }^{2}$ Professor, Department of Horticulture

${ }^{3}$ Professor, Department of Agronomy and Soils

${ }^{4}$ Research Associate, Department of Discrete and Statistical Sciences

${ }^{5}$ Director, E.V. Smith Research Center

Alabama Agricultural Experiment Station

Auburn University, AL 36849

\section{* Corresponding author}

Résumé. Le taux en éléments minéraux dans le sol et les feuilles de caryers de l'Illinois (Carya illinoensis) a été comparé entre divers traitements: arbres avec un paillis de feuilles, d'écorce de pin grossière, de paille de pin, de brins de gazon tondu ou de copeaux de bois; arbres en parterre gazonné sans paillis autour; arbres sans paillis dont la végétation est contrôlée autour par l'application d'herbicides. Le sol sous le paillis de brindilles de gazons avait des taux accrus en potassium (K) dans le sol comparativement à tous les autres traitements sauf celui avec les copeaux de bois. Les arbres avec paillis de copeaux de bois avaient des taux de $\mathrm{pH}$ de sol plus élevés que ceux avec un paillis de brins de gazon tondu, ceux en parterre gazonné sans paillis autour, ou ceux sans paillis avec application d'herbicides. Les arbres avec paillis avaient des troncs $60 \%$ plus gros en surface terrière comparativement aux arbres en parterre gazonné sans paillis autour ou les arbres sans paillis avec application d'herbicides, et ce tout au long des trois années de cette étude. Les différences nutritives entre les divers paillis utilisés étaient faibles, suggérant de ce fait que les différences de croissances sont attribuables à d'autres facteurs. 
Zusammenfassung. Die Nährstoffkonzentration von Boden und Blättern bei jungen Pecannußbäumen (Carya illinoensis), die mit Blättern, Kiefernrindenmulch, Kiefernnadeln, Grasschnitt oder Holzhächsel gemulcht wurden, wurden verglichen mit ungemulchten Bäumen mit Grasnarbe und ungemulchten mit Herbizideinsatz. Der Boden unter dem Grasschnitt zeigte im Vergleich mit allen anderen Behandlungen außer Holzhächsel einen Anstieg des Kaliumgehaltes. Die Holzhächselmulchung zeigte einen höheren pH-Wert als Grasschnitt, ungemulchte mit Grasnarbe und ungemulchte mit Herbizidkontrolle. In dieser dreijährigen Studie wuchsen gemulchte Bäume ca. $60 \%$ mehr im Stammdurchmesser als die anderen mit Grasnarbe und Herbizideinsatz. Die Nährstoffunterschiede zwischen den verschiedenen Mulchbehandlungen waren gering, was darauf hinweist, daß die Wachstumsunterschiede anderen faktoren zuzuschreiben sind.
Resumen. Fueron comparados los niveles minerales en el suelo y en las hojas de árboles pacanas jövenes (Carya illinoensis) mulcheados con hojas, pedazos de corteza de pino, paja de pino, pasto cortado de poda, o ramas trituradas; árboles con pasto no mulcheados; y árboles con vegetaciön controlada con herbicidas no mulcheados. El suelo bajo el mulch de pasto cortado moströ un incremento en los niveles de potasio (K) al ser comparado con todos lo otros tratamientos, excepto con las ramas trituradas. El tratamiento con las ramas trituradas tiene un $\mathrm{pH}$ del suelo más alto que el pasto cortado, árboles con pasto no mulcheados o árboles con vegetaciön controlada con herbicidas no mulcheados. Los árboles mulcheados crecen aproximadamente $60 \% \mathrm{~m}$.s en las áreas de la secciön transversal del tronco, comparados con los árboles con pasto o vegetaciön controlada, en estos 3 años de estudio. Las diferencias minerales entre los mulches fueron pequeñas, sugiriendo que las diferencias en crecimiento pueden ser atribuidas a otros factores. 